\title{
Literasi Wakaf Uang Berbasis Masjid
}

\section{The Literacy of Cash Waqf based on Mosque}

\author{
Acep Zoni Saeful Mubarok \\ Fakultas Agama Islam Universitas Siliwangi Tasikmalaya \\ email: accefs@unsil.ac.id \\ Artikel diterima 10 April 2021, diseleksi 17 April 2021 \\ dan disetujui 05 Juli 2021
}

\begin{abstract}
Abstrak: Tujuan penelitian ini adalah untuk mengkaji apakah masjid dapat digunakan secara efektif untuk membangun literasi wakaf uang. Kemudian strategi apa yang harus dilakukan dalam memanfaatkan masjid sebagai pusat literasi uang tersebut. Hal ini dikarenakan masjid merupakan tempat berkumpulnya umat Islam dan menjadi sentra kegiatan masyarakat muslim dalam segala hal. Metode yang digunakan pada kajian ini adalah kualitatif deskriptif yang bersumber dari kajian kepustakaan. Hasil dan temuan yang didapat dari studi ini adalah strategi dalam literasi wakaf uang berbasis masjid ini dapat dilakukan dengan cara sebagai berikut: pertama, membangun kerjasama dengan organisasi yang memiliki tugas dan fungsi pembinaan kemasjidan, yaitu Dewan Masjid Indonesia (DMI), Badan Koordinasi Majelis Taklim Masjid (BKMM) dan Badan Komunikasi Pemuda Remaja Masjid (BKPRMI). Kedua, menyusun materi majeis taklim dan khutbah tentang wakaf uang supaya menjadi bekal materi bagi para da'i dan khatib dan ketiga, menyelenggarakan Training of Trainer (TOT) bagi para khatib dan da'i.
\end{abstract}

Kata Kunci: wakaf uang, literasi, masjid

Abstract: The purpose of this study is to examine whether mosque can be used effectively to build cash waqf literacy. Then what strategy should be used in utilizing the mosque as a money literacy center. The reason is the mosque gathering place for Muslim and the center of Muslim community activities in all 
respects. The method uses in this study is a descriptive qualitative sourced from literature review. The results and findings obtain from this study are the strategies in cash waqf literacy based on mosque, it can be carried out in the following: first, building cooperation with organizations that have the duties and functions of mosque development, namely the Indonesian Mosque Council (DMI), the Taklim Council Coordinating Board Mosque (BKMM) and Mosque Youth Communication Agency (BKPRMI). Second, compiling material for taklim and sermon on cash waqf issues so that they become material provisions for preachers (Da'i and Khatib) and third, organizing Training of Trainers (TOT) for preachers (Da'i dan Khatib).

Keywords: cash waqf, literacy, mosque

\section{A. Pendahuluan}

Preferensi masyarakat Indonesia terhadap wakaf uang masih rendah. Hal ini seperti yang disampaikan Direktur Jenderal Bimbingan Masyarakat Islam Kementerian Agama RI pada Rakornas BWI tanggal 30 Maret 2021 bahwa sampai saat ini pengumpulan wakaf uang secara nasional baru terkumpul sekitar Rp. 831 milyar dari potensi wakaf uang sekitar Rp. 180 trilyun setiap tahunnya. ${ }^{1}$ Potensi ini jika dibanding dengan negara lain di dunia, Indonesia jauh melampaui lainnya. Selain aset wakaf berupa tanah yang terbentang dari Sabang sampai Merauke seluas 53.255,66 Ha dan tersebar di 398.434 titik, ${ }^{2}$ populasi penduduk muslim yang besar akan sangat mendukung pengembangan wakaf uang.

Realitas yang ada, Indonesia masih ketinggalan dalam pengembangan wakaf uang. Beberapa negara tetangga di Asia Tenggara sudah mulai memanfaatkan potensi wakaf uangnya dengan sangat baik, diantaranya Malaysia dan Singapura. Pada mulanya aset wakaf di negeri jiran ini tidak terurus dengan baik. ${ }^{3}$ Akan tetapi Malaysia mampu mengelola wakaf tunai melalui Bank Muamalat Malaysia Berhad. Pada tahun 2015 jumlah wakaf tunai yang berhasil dihimpun, tercatat sebesar Rp. 26.932.690.554,00. 
Tidak ketinggalan negara Singapura, walaupun bukan negara mayoritas muslim memanfaatkan potensi wakaf negaranya dengan program aset wakaf dibiayai melalui peluncuran Sukuk atau obligasi syariah di pasar modal menggunakan akad bagi hasil yang dikenal dengan "Musharakah Bond". Sukuk tersebut diluncurkan untuk membiayai dua proyek wakaf produktif yang bernilai 60 juta dolar Singapura (Rp. 585 miliar rupiah). ${ }^{4}$

Selain di beberapa negara Asia Tenggara, negara di belahan lain seperti Arab Saudi, Mesir, Yordania, dan Turki sudah terlebih dahulu memberdayakan wakaf uang ini. Di Pakistan wakaf uang ini dikenal dengan istilah cash wakaf atau waqf an-nuqud, ${ }^{5}$ bahkan di Bangladesh wakaf uang ini justru yang dapat meningkatkan kesejahteraan rakyat dari kemiskinan. ${ }^{6}$

Untuk mengejar ketertinggalan ini, sesungguhnya Indonesia sudah berbenah diri. Sebagai langkah pertama diawali dengan menerbitkan regulasi sebagai dasar legal standing dalam pengembangan wakaf yaitu berupa Undang-undang No. 41 Tahun 2004 tentang wakaf ${ }^{7}$. Selain itu, dukungan pemerintah semakin memperkuat pengembangan wakaf uang setelah Presiden RI meluncurkan Gerakan Nasional Wakaf Uang (GNWU). ${ }^{8}$

Kemudian apa yang menjadikan penyebab Indonesia belum secara maksimal pengembangan wakaf uang. Salah satu penyebab belum optimalnya wakaf uang di Indonesia adalah karena minimnya literasi dan edukasi..$^{9}$ Menurut penelitian Badan Wakaf Indonesia dan Kementerian Agama RI, Indeks Literasi Wakaf (ILW) masih masuk kategori rendah, yaitu dengan skor 50,48 yang terdiri dari Nilai Literasi Pemahaman Wakaf Dasar sebesar 57,67 serta Nilai Literasi Pemahaman Wakaf Lanjutan sebesar 37,97. Hal ini dapat dilihat pada table 1. 
Tabel 1

Skor Indeks Literasi Wakaf Per-Dimensi

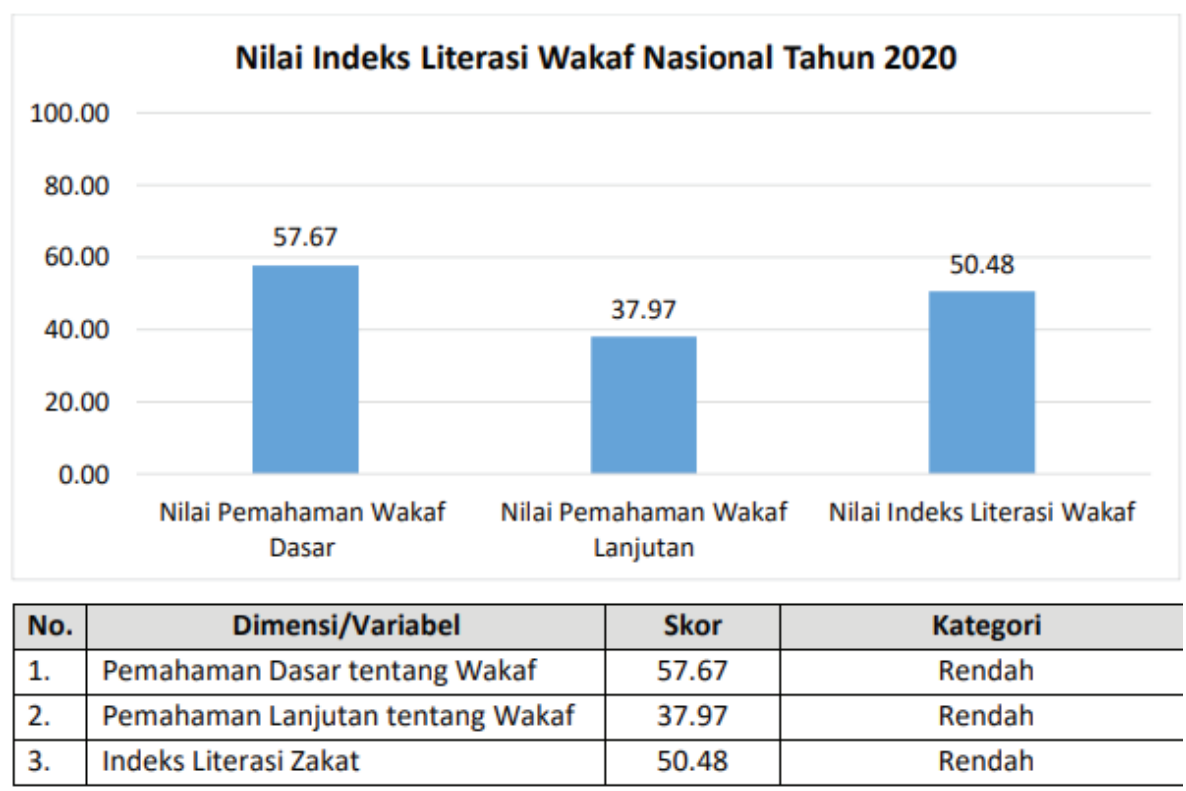

Sumber Data: Badan Wakaf Indonesia ${ }^{10}$

Data ini menggambarkan pemahaman masyarakat muslim Indonesia secara keseluruhan tentang wakaf. Apalagi pemahaman lanjutan tentang wakaf termasuk kategori rendah. Terlebih dalam masalah wakaf uang, masyarakat masih banyak yang belum memahami apa dan bagaimana wakaf uang. Selama ini pemahaman masyarakat muslim Indonesia adalah wakaf yang berguna adalah saat aset tersebut nampak dan memiliki kemanfaatan yang kekal, seperti tanah dan benda tidak bergerak lainnya. Hal ini dapat dilihat dari preferensi masyarakat terhadap wakaf uang sebagaimana dalam tabel 2. 


\section{Tabel 2}

Preferensi Masyarakat terhadap Jenis Wakaf

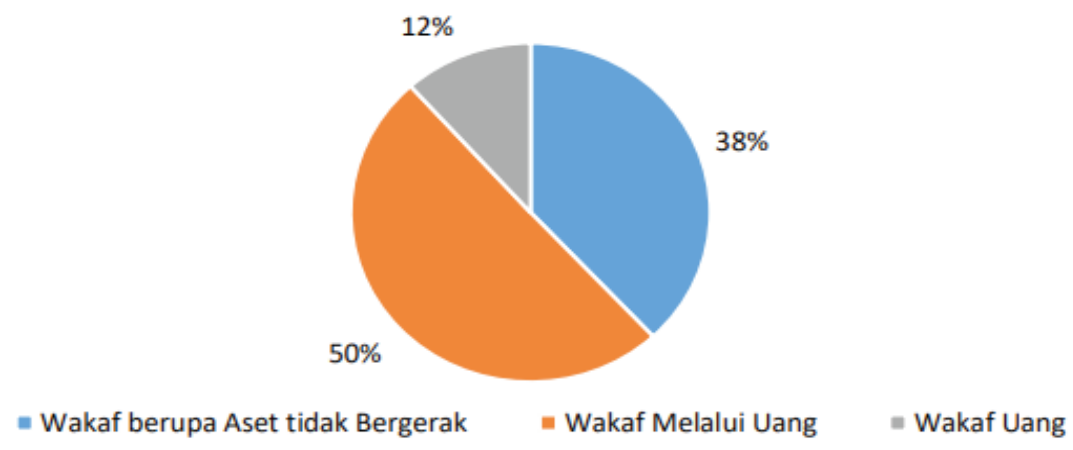

Sumber Data: Badan Wakaf Indonesia ${ }^{11}$

Dari tabel ini dapat dibaca preferensi masyarakat terhadap wakaf selain uang masih tinggi. Masyarakat masih cenderung terhadap wakaf melalui uang atau dengan benda tidak bergerak. Pada praktiknya pelaksanaan wakaf uang lebih mudah. Dalam wakaf uang, barang wakafnya adalah uang kemudian dikelola secara produktif dan hasilnya secara langsung dimanfaatkan oleh penerima wakaf. Berbeda dengan wakaf melalui uang yang merupakan cara berwakaf dengan memberikan uang untuk dijadikan harta wakaf, baik bergerak ataupun tidak bergerak.

Kemudahan dalam berwakaf uang belum begitu banyak diketahui khalayak. Hal ini dapat disebabkan keterbatasan inklusi dan awareness masyarakat terhadap wakaf uang serta dakwah di masyarakat belum secara massif memperkenalkan wakaf uang.

Untuk meningkatkan literasi wakaf uang ini, Direktorat Jenderal Bimas Islam Kementerian Agama RI memiliki 5 (lima) langkah strategis berupa optimalisasi sosialisasi literasi wakaf secara nasional, ${ }^{12}$ yaitu optimalisasi melalui penyuluh dan Kantor Urusan Agama, optimalisasi melalui sosial media, optimalasisai melalui nazhir, optimasliasi melalui lembaga pendidikan, dan optimalisasi melalui masjid majelis taklim dan 
ormas. Kelima unsur ini dianggap mampu mewakili bagian terpenting dari masyarakat muslim di Indonesia.

Dari kelima unsur tersebut, ada potensi besar yang apabila memaksimalkan literasi di tempat itu akan sangat efektif. Potensi tersebut adalah masjid. Masjid secara literal dapat dimaknai sebagai sarana ibadah yang universal. Keberadaannya tidak hanya diperuntukan ibadah mahdhah (mikro), tetapi juga ibadah ghair mahdhah (makro). Fungsi masjid seperti itu secara jelas tergambar sebagaimana pada masa Rasulullah SAW, karena pada masanya eksistensi masjid selain tempat ibadah juga tempat pusat kegiatan umat termasuk pusat pendidikan masyarakat.

Informasi, edukasi dan literasi yang bersumber dari masjid akan sangat mudah diterima oleh masyarakat secara langsung. Sehingga masjid memiliki potensi strategis dalam mengembangkan literasi masyarakat tentang wakaf uang. Apalagi, Indonesia merupakan negara yang memiliki jumlah masjid dan mushalla yang banyak. Menurut data statistik dari Sistem Informasi Masjid (SIMAS) Kementerian Agama RI, tedapat sejumlah 270.259 Masjid dan 316.470 Mushalla ${ }^{13}$.

Studi ini akan mengkaji bagaimana strategi yang dibangun dalam mengembangakan literasi wakaf uang terhadap masyarakat berbasis masjid. Tujuan dari studi ini adalah untuk mengetahui bagaimana kedua potensi ini disatukan. Potensi wakaf uang yang masih perlu didayagunakan dengan potensi masyarakat masjid yang sangat besar. Kajian ini menggunakan metode kualitatif deskriptif yang bersumber dari kajian kepustakaan baik dari buku referensi maupun jurnal-jurnal.

\section{B. Hasil dan Pembahasan}

Dalam babakan sejarah umat Islam, masjid dan wakaf merupakan dua hal yang tidak bisa dilepaskan. Jika dicermati hampir semua dukungan pembangunan fisik dan fasilitas masjid bersumber dari wakaf, infak dan sedekah. Pada perkembangan selanjutnya bermula dari hanya 
wakaf untuk masjid kemudian melebar menjadi wakaf untuk lembaga pendidikan seperti pesantren, majelis taklim, sekolah rumah sakit, dan panti asuhan. ${ }^{14}$

\section{Paradigma Baru Wakaf}

Wakaf merupakan salah satu tema kajian menarik di kalangan para ulama baik klasik maupun kontemporer. Hal ini karena wakaf merupakan salah satu filantropi dalam Islam yang dianjurkan oleh syari'at dan senantiasa diamalkan langgeng dari generasi awal sampai sekarang. Disamping itu secara esensial wakaf memiliki dua fungsi utama yaitu fungsi ibadah ritual yang bertujuan pengabdian kepada Allah SWT dan fungsi muamalah untuk mewujudkan kesejahteraan sosial.

Dari latar tersebut, wakaf merupakan amaliyah ubudiyah yang dapat dirasakan secara langsung kemanfaatannya secara sosial. Hal ini tidak lepas dari makna wakaf itu sendiri al-habs (menahan). ${ }^{15}$ Lebih rinci Imam Nawawi memberikan definisi atas wakaf dengan: Menahan harta yang dapat dimanfaatkan tanpa lenyap bendanya, dengan cara tidak melakukan tindakan hukum terhadap benda-benda tersebut disalurkan pada sesuatu yang diperbolehkan. ${ }^{16}$

Dari pengertian wakaf tersebut melahirkan prinsip-prinsip wakaf diantaranya aset wakaf harus kekal dan dimanfaatkan untuk kepentingan yang diperbolehkan oleh syara. Menurut pandangan ulama Hanafiyah wakaf merupakan sedekah yang kedudukannya seperti pinjam meminjam (ariyah). Jadi harta yang diwakafkan adalah milik wakif sedangkan yang disedekahkan adalah hanya manfaatnya saja. ${ }^{17}$

Makna wakaf menurut pandangan ulama klasik telah melahirkan inspirasi baru makna wakaf kontemporer. Seperti halnya dalam regulasi yang diterbitkan oleh Indonesia melalui Undang-undang No. 14 Tahun 2004 tentang wakaf. Dalam pasal 1 ayat 1 Undang-undang tersebut pengertian wakaf adalah perbuatan hukum wakif untuk memisahkan dan/atau menyerahkan sebagian harta benda miliknya 
untuk dimanfaatkan selamanya atau untuk jangka waktu tertentu sesuai dengan kepentingannya guna keperluan ibadah dan/atau kesejahteraan umum menurut syariah. ${ }^{18}$

Pengertian yang diterbitkan oleh Undang-undangan ini memberikan paradigma baru berwakaf di Indonesia, termasuk adanya wakaf uang. Dari pemahaman konsep wakaf klasik yang berpatokan pada benda wakaf tidak bergerak dan tidak lenyap telah mengalami pergeseran kepada benda bergerak. Selain itu muncul pula pergesaran konsep dari wakaf abadi kepada konsep tidak abadi (sementara).

Munculnya beraneka macam wakaf sekarang ini dikarenakan paradigma baru wakaf yang dibangun. Asas paradigma baru tersebut meliputi:pertama, asaskeabadianmanfaat;keduaasaspertanggungjawaban/ responsibility; ketiga, asas profesionalitas manajemen; dan kelima, asas keadilan sosial. Sedangkan aspek-aspek paradigma baru wakaf meliputi: pertama, pembaharuan/reformasi pemahaman mengenai wakaf; Kedua, system manajeman pengelolaan yang professional; Ketiga, system manajemen kenazhiran; Keempat, system rekruitmen wakif. ${ }^{19}$

Paradigma baru tersebut menjadi landasan membangun wakaf yang lebih produktif untuk pengembangan wakaf yang lebih berdayaguna dan berhasil guna. Salah satu keberhasilan dari paradigm baru tersebut adalah dengan munculnya inovasi wakaf selain wakaf tanah, seperti halnya wakaf satuan rumah susun, wakaf air dan bahan bakar minyak, wakaf kendaraan, wakaf Hak Atas Kekayaan Intelektual (HAKI), wakaf Surat Berharga, wakaf obligasi, Cash Waqf Linked Sukuk (CWLS), wakaf polis asuransi, Surat Utang Negara (SUN) ${ }^{20}$ dan wakaf uang.

\section{Landasan Wakaf Uang}

Uang memiliki posisi penting dalam kegiatan transaksi ekonomi di dunia. Uang sekarang berbeda dengan masa lampau. Uang selain memiliki fungsi alat tukar, tapi juga dianggap sebagai benda bahkan menjadi sesuatu yang diperjualbelikan di berbagai bank dan money 
changer. Dari sinilah wakaf uang dapt dijadikan objek wakaf.

Wakaf uang masih merupakan hal baru di masyarakat, karena selama ini objek wakaf dipersepsikan hanya berupa benda tidak bergerak seperti tanah. Kekhawatiran lain karena wakaf uang dianggap tidak pernah ada dalam kajian kitab-kitab fikih sehingga terjadi perdebatan tentang kebolehannya.

Terlepas dari terdapat pro dan kontra dalam hal ini, sebenarnya kajian wakaf uang ini sudah menjadi kajian yang menarik di kalangan ulama. Walaupun terdapat ulama yang tidak setuju, seperti Ibnu Qudamah, asySyirazi, dan Al-Bakri. Alasan yang dikemukakan oleh mereka diambil dari aspek kekekalan zat harta wakaf. Uang jika dimanfaatkan zatnya akan habis dan tidak kekal, ini bertentangan dengan hadits Rasulullah SAW yang memerintahkan kepada Umar r.a untuk "menahan pokoknya dan menyedekahkan hasilnya". ${ }^{21}$

Ulama lain seperti Imam Zuhri, Abu Tsaur, Imam Hanafi, dan AsySyaibani memperbolehkan praktik wakaf uang. Imam Hanafi bersandar pada hukum 'urf (kebiasaan) dan pendapat Abdullah bin Masud, yang menyatakan bahwa apa yang dipandang baik oleh seorang muslimmaka akan dipandang baik pula oleh Allah. Pendapat ini diperkuat oleh AsySyaibani yang menyatakan bahwajika wakaf uang telah menjadikebiasaan di suatu daerah maka tidak mengapa untuk dilanjutkan. Karena kekekalan tidak hanya dapat dicapai melalui zatnya tetapidapat dicapai juga melalui kekekalan manfaat yang didapat. ${ }^{22}$

Untuk di Indonesia Majelis Ulama Indonesia (MUI) telah menerbitkan fatwa tanggal 11 Mei $2002^{23}$ yang membolehkan wakaf uang dengan ketentuan harus disalurkan dan digunakan untuk hal-hal yang dibolehkan secara syar'i serta nilai pokok wakaf uang tersebut harus dapat dijamin kelestariannya, tidak boleh dijual, dihibahkan, atau diwariskan. Fatwa ini yang dijadikan rujukan utama dalam Undang-Undang No. 41 Tahun 2004 tentang wakaf. $^{24}$ 
Pengertian wakaf uang lebih detail terdapat dalam Peraturan BWI No. 1 Tahun 2009 pasal 1 ayat 3 yang menyebutkan bahwa "Wakaf harta benda bergerak berupa uang yang selanjutnya disebut wakaf uang adalah wakaf berupa uang yang dapat dikelola secara produktif, hasilnya dimanfaatkan untuk mauquf alaih. ${ }^{25}$ Dalam hal ini harus dibedakan pula antara wakaf uang dengan wakaf melalui uang. Kalau wakaf uang adalah wakaf berupa uang yang dapat dikelola secara produktif, hasilnya dimanfaatkan untuk mauquf alaih, sedangkan wakaf melalui uang adalah bagian dari wakaf uang yang penyerahannya dalam bentuk uang melalui LKS PWU senilai harga barang yang dimaksud. ${ }^{26}$

Sedangkan untuk model pengawasan wakaf uang disebutkan dalam pasal 10 disebutkan bahwa Direktur Jenderal atas nama Menteri melakukan pengawasan wakaf uang yang dilakukan oleh LKS-PWU. Sedangkan dalam Pasal 12 disebutkan bahwa:

a. BWI melakukan pengawasan pengelolaan dan pengembangan wakaf uang yang dilakukan oleh Nazhir.

b. Pengawasan sebagaimana dimaksud pada ayat (1) melalui laporan tahunan, monitoring dan evaluasi pengelolaan dan pengembangan wakaf uang yang dilakukan oleh Nazhir.

c. Hasil pengawasan sebagaimana dimaksud pada ayat(2) digunakan sebagai dasar penilaian kinerja dan sebagai bahan pembinaan terhadap Nazhir.

d. BWI dapat menunjuk Akuntan Publik untuk memeriksa laporan pengelolaan, pengembangan, dan pemanfaatan hasil pengelolaan wakaf uang yang dilakukan oleh Nazhir.

Dengan mengikuti beberapa regulasi tersebut, terdapat beberapa manfaat wakaf uang yang sudah diprogramkan dan terlaksana dengan baik di Indonesia. Diantara manfaat tersebut adalah berupa Program Pemakaman Berbasis Wakaf Produktif yang dikembangkan oleh lembaga Wakaf Pro99 Bandung. Selain itu terdapat pula Program Polis Asuransi 
Berbasis Wakaf Produktif yang dikembangkan oleh Lembaga Wakaf alAzhar Jakarta. Termasuk Program Rumah Sakit Bersalin Berbasis Wakaf Produktif yang kelola oleh lembaga wakaf Rumah Wakaf Indonesia (RWI) Bandung serta Program Wakaf Perkebunan Berbasis Wakaf Produktif Program ini dikembangkan oleh lembaga Tabung Wakaf Indonesia (TWI). ${ }^{27}$

Untuk di Provinsi Daerah Istimewa Yogyakarta Badan Wakaf Indonesia wilayah Kota Yogyakarta telah berhasil membina beberapa nazhir wakaf uang diantaranya Badan Wakaf Uang Tunai Majelis Ulama Indonesia (BWUT-MUI), Dewan Masjid Indonesia (DMI), KJKS BMT Beringharjo, KSP BMT Al-Ikhlas, dan BMI BMT Bina Ihsanul Fikri. ${ }^{28}$

Perkembangan wakaf uang di Indonesia sudah mulai menggeliat, tetapi belum sesemarak zakat, untuk itu diperlukan edukasi dan literasi yang lebih efektif ke masyarakat secara langsung. Beberapa contoh perkembangan di atas cukup menggembirakan walaupun masih terbatas pada lembaga-lembaga tertentu. Diharapkan masjid dapat dijadikan sarana strategis untuk mengedukasi masyarakat suapaya lebih memahami wakaf uang dan dapat diamalkan dengan baik.

\section{Masjid dan Potensi Umat}

Hampir semua masjid didirikan di atas tanah wakaf. Demikian pula lahirnya wakaf-wakaf umat adalah insiatif masyarakat masjid. Kedua sejoli ini yaitu amaliyah wakaf dan masjid merupakan inspirasi berkembangnya wakaf di dunia Islam. Makna masjid yang terambil dari akar kata sajada-yasjudu memiliki arti patuh, taat, serta tunduk dengan penuh hormat dan takzim ${ }^{29}$. Pengertian terpendek dari masjid adalah tempat sujud, ${ }^{30}$ sedangkan dalam pengertian terminologis diartikan sebagai tempat beribadah umat Islam, khususnya dalam menegakkan shalat. Masjid sering disebut Baitullah (rumah Allah), yaitu bangunan yang didirikan sebagai sarana mengabdi kepada Allah.

Secara historis, saat Nabi Muhammad SAW hijrah ke Madinah melewati daerah Quba. Di tempat ini pertama sejak masa kenabiannya, 
Nabi mendirikan Masjid Quba yang disebut Allah SWT sebagai "Masjid yang didirikan atas dasar takwa sejak hari pertama"(QS 9 : 108). ${ }^{31}$ Setelah di Madinah Rasulullah SAW juga mendirikan masjid sebagai tempat melaksanakan shalat berjama'ah dan pusat aktivitas sosial lainnya yang pada perkembangannya dikenal dengan nama Masjid Nabawi. ${ }^{32}$

Peranan masjid dalam kehidupan umat Islam di masa lalu begitu besar. Fungsi masjid selain sebagai tempat pelaksanaan ibadah, masjid dipergunakan sebagai sentra aktivitas sosial. Misalnya, sebagai tempat musayawarah, pengobatan, latihan dan siasat perang, tempat pendidikan serta usaha ekonomi masyarakat. ${ }^{33}$

Inti dari hasil Muktamar "Risalatul Masjid" pada tahun 1975 di Makkah, adalah pada perkembangannya fungsi masjid bukan saja tempat sujud dalam arti sempit, tetapi juga tempat beribadah kepada Allah yang tidak hanya terbatas pada peribadatan mahdlah (vertical) tetapi juga peribadahan dalam dimensi horizontal.

Indonesia dengan bonus demografi penduduk muslim terbesar di dunia, tentu tidak akan lepas dari peran masjid dalam kehidupan kesehariannya. Jumlah masjid yang terebar di seluruh penjuru tanah air dapat dikatakan sebagai negara berjuta masjid. Hal ini dapat dicermati dari data jumlah masjid dan mushalla di Indonesia pad table 4 dan 5.

Tabel 4

Data Masjid se-Indonesia Berdasarkan Tipologi

\begin{tabular}{|l|l|}
\hline \multicolumn{1}{|c|}{ Tipologi Masjid } & \multicolumn{1}{c|}{ Jumlah } \\
\hline Masjid Negara & 1 \\
\hline Masjid Raya & 34 \\
\hline Masjid Agung & 420 \\
\hline Masjid Besar & 4803 \\
\hline Masjid Jami & 225641 \\
\hline Masjid Bersejarah & 964 \\
\hline Masjid di Tempat Publik & 45102 \\
\hline
\end{tabular}

Sumber: Data Sistem Informasi Masjid (SIMAS) Kementerian Agama ${ }^{34}$ 
Tabel 5

Data Mushalla se-Indonesia Berdasarkan Tipologi

\begin{tabular}{|l|l|}
\hline \multicolumn{1}{|c|}{ Tipologi Mushalla } & \multicolumn{1}{c|}{ Jumlah } \\
\hline Mushalla di tempat Publik & 81.511 \\
\hline Mushalla di Perkantoran & 3.585 \\
\hline Mushalla Pendidikan & 11.629 \\
\hline Mushalla Perumahan & 228.378 \\
\hline
\end{tabular}

Sumber: Data Sistem Informasi Masjid (SIMAS) Kementerian Agama ${ }^{35}$

Tersebarnya masjid dan mushalla di Indonesia, merupakan sebuah modal terbesar bagi bangsa Indonesia dalam membangun kesadaran beragama terutama wakaf. Apalagi, selama ini masjid tidak dapat dipisahkan dari wakaf, demikian juga wakaf tidak dapat dipisahkan dari masjid. Berdirinya masjid di tengah-tengah masyarakat hampir dipastikan bersumber dari wakaf masyarakat. Preferensi masyarakat dalam memilih wakaf untuk bangunan masjid lebih tinggi, karena atas dasar kepatuhan terhadap ajaran agama.

Eksistensi masjid selama ini merupakan sentral kegiatan umat. Termasuk pusat literasi masyarakat dalam kegiatan kemasyarakatan yang dipimpin langsung oleh tokoh agama (ulama atau ustadz). Dari corong public figure ini masyarakat digerakkan. Kegiatan rapat-rapat yang berskala besar pun biasanya dilaksanaakan di masjid sampai pengumuman kematian, gotong royong dan kegiatan-kegiatan lainnya pun banyak melibatkan masjid.

Masjid juga kadang menjadi sasaran empuk para politisi menjelang pemilihan umum atau pemilihan kepala daerah dari mulai gubernur sampai kepala desa. Termasuk juga pendekatan-pendekatan yang dilakukan oleh para calon selama pemilihan legislatif. Sudah dipastikan menjelang pemilihan, KPU menerbitkan larangan penggunaan rumah ibadah (masjid) untuk tujuan politik. ${ }^{36} \mathrm{Hal}$ ini dilakukan masjid tempat berkumpulnya umat Islam sangat efektif untuk menyampaikan informasi secara langsung kepada masyarakat. Selain itu kehadiran ulama sebagai 
pemimpin dan pengajar agama di masjid sangat dipatuhi oleh jama'ah masjid.

\section{Literasi Berbasis Masjid}

Literasi dan masjid merupakan dua hal yang tidak dapat dipisahkan. Sejak zaman Rasusullah SAW masjid memiliki fungsi sebagai sentra talim wat-ta'allum yang dalam istilah sekarang dikenal dengan literasi (literacy) alias kemelekan huruf. ${ }^{37}$ Menurut pengertian modern literasi ini didefinisakan sebagaimana menurut Grabe \& Kaplan dan Graff yaitu sebagai kemampuan untuk membaca dan menulis (able to read and write), ${ }^{38}$ sedangkan orang yang mampu keduanya disebut literat. ${ }^{39}$ Literasi dapat dimaknai merupakan kemampuan membaca, menulis, memandang, dan merancang suatu hal yang disertai kemampuan berpikir kritis sehingga menyebabkan sesorang mampu berkomunikasi dengan efektif dan efesien. ${ }^{40}$

Literasi dapat dilaksanakan di mana saja termasuk di rumah ibadah seperti masjid. Apalagi masjid memiliki keterkaitan dengan masyarakat secara langsung, tidak hanya terkait masalah keagamaan saja. Dengan adanya tokoh agama di masjid (kyai, ustadz) yang selalu mengajarkan pendidikan agama dan pemberi solusi dalam berbagai persoalan, masjid sangat strategis sebagai pusat literasi dalam berbagai hal termasuk wakaf uang.

Pendekatan kultural yang bersifat tradisional dari tokoh agama di masjid justru akan sangat membantu menyampaikan sesuatu hal yang dianggap sulit. Demikian pula dengan pengaruh tokoh agama (ulama) di masjid dalam pengembangan literasi wakaf uang akan menjadi lebih ringan dan efektif.

Strategi utama dalam perancangan program literasi berbasis masjid ini harus dimulai dari pemangku kebijakan dalam hal ini Kementerian Agama atau Badan Wakaf Indonesia (BWI) di setiap Kota dan Kabupaten se-Indonesia. Langkah pertama adalah mengedukasi kepada para 
ustadz, khatib dan Ketua DKM. Salah satu strategi dalam literasi wakaf uang berbasis masjid ini dapat dilakukan dengan cara sebagai berikut:

\section{a. Membangun Kerjasama}

Kerjasama sangat dibutuhkan dalam bermasyarakat karena manusia merupakan makhluk sosial. Kerjasama pada hakikatnya mengindikasikan adanya dua pihak atau lebih yang berinteraksi secara dinamis, ${ }^{41}$ untuk menggapai tujuan bersama yang hendak dicapai. ${ }^{42}$

Dalam memberikan literasi kepada masyarakat, baik Kementerian Agama maupun Badan Wakaf Indonesia (BWI) di Kota dan Kabupaten dapat bekerjasama secara sinergis dengan stakeholder yang berhubungan dengan kemasjidan. Tentu dalam hal ini ada beberapa lembaga yang memiliki tugas dan fungsi pembinaan kemasjidan, diantaranya Dewan Masjid Indonesia (DMI). ${ }^{43}$ Badan Koordinasi Majelis Taklim Masjid (BKMM) dan Badan Komunikasi Pemuda Remaja Masjid (BKPRMI). ${ }^{44}$

Organisasi-organisasi ini merupakan representasi dari tiga golongan masyarakat yang aktif dan menjadi pioner imarah di masjid. Pertama, Dewan Masjid Indonesia (DMI) ${ }^{45}$ merupakan organisasi kemasjidan yang memiliki tujuan untuk mewujudkan fungsi masjid sebagai pusat ibadah, pengembangan masyarakat dan persatuan umat. Bisa dikatan bahwa DMI representasi dari jamaah masjid laki-laki. Karena DMI Kota Kabupaten ini memiliki fungsi membina Dewan Kemakmuran Masjid (DKM) mulai dari masjid kategori/tipologi Masjid Jami, Masjid Besar, Masjid Agung.

Kedua, BKMM (Badan Koordinasi Majelis Taklim Masjid). Badan Kerjasama Majelis Taklim Masjid (BKMM) merupakan organisasi otonom (ortom) Dewan Masjid Indonesia (DMI) yang berasaskan Islam, bersifat pemberdayaan dan kekeluargaan. Kepengurusan BKMM ini adalah ibu-ibu yang bertujuan untuk mempersatukan Majelis Taklim Masjid guna peningkatan kesejahteraan masyarakat 
dengan memakmurkan majelis taklim masjid. Dapat dikatakan organisasi ini adalah representasi dari jamaah perempuan atau ibu-ibu.

Ketiga, Badan Komunikasi Pemuda Remaja Masjid (BKPRMI) ${ }^{46}$ yang merupakan organisasi bertujuan memberdayakan dan mengembangkan potensi Pemuda Remaja Masjid. Organisasi ini membina remaja-remaja masjid di setiap masjid dan mushalla. Literasi wakaf uang akan sangat efektif jika diberikan kepada generasi muda atau remaja. Pelibatan terhadap remaja masjid ini merupakan suatu hal yang esensial guna keberlangsungan program dalam jangka panjang.

Untuk penguatan remaja masjid di setiap masjid dan mushalla, stakeholder wakaf uang dapat menggandeng BKPRMI sebagai salah satu wadah yang dalam tugas dan fungsinya adalah memberikan pengkaderan generasi masjid didalam bentuk pengkaderan remaja masjid. Remaja masjid merupakan generasi muda yang ke depan akan menjadi tokoh masyarakat (iron stock). Usia yang masih muda serta semangat yang tinggi menjadikan remaja masjid memiliki daya juang dan loyalitas tinggi.

Perlunya penyampaian dakwah wakaf uang kepada beberapa pihak, ini bertujuan agar program wakaf uang lebih efektif dan langsung sampai kepada masyarakat bawah . Organsiasiorganisasi ini (DMI, BKMM, BKPRMI) sangat berpengaruh di daerah dan sangat bersentuhan langsung dengan masyarakat. Dengan menggandeng beberapa organsiasi-organisasi ini akan sangat efektif dalam menyampaikan materi wakaf uang.

b. Menyusun Materi Majeis Taklim dan Khutbah Tentang Wakaf Uang

Salah satu cara meningkatkan literasi masyarakat di masjid dengan membangun kerjasama dengan beberapa organisasi. Tetapi tidak kalah penting lagi dari itu semua adalah menyediakan bahan materi 
untuk literasi itu sendiri. Salah satunya adalah penyediaan materi dan tema wakaf uang yang akan dibawakan oleh penceramah dalam berbagai kegiatan ceramah, baik pengajian ataupun khutbah jumat. Tentu, dengan adanya materi yang tersampaikan dengan baik kepada audiens, diharapkan masyarakat lebih faham tentang wakaf dan pada akhirnya Indeks Literasi Wakaf akan semakin membaik. Karena selama ini pengajian terutama khutbah jumat yang dihadiri oleh banyak orang sangat efektif sebagai sarana untuk menyampaikan pesan. ${ }^{47}$

Di sini peran Kementerian Agama dan Badan Wakaf Indonesia (BWI) Kota dan Kabupaten sangat berperan untuk menyampaikan pencerahan berupa buku materi wakaf uang yang disusun secara sistematis. Para ulama atau ustadz di masjid merupakan tokoh keagamaan yang sangat dihormati dan diikuti oleh masyarakat. Namun tidak semua para ustadz, mubalig dan kyai memahami seluk beluk wakaf apalagi materi wakaf kontemporer seperti wakaf uang, baik dari dimensi hukum fikih maupun perundangan, termasuk fatwa MUI tentang wakaf uang dan prosedur yang harus ditempuh saat jamaah hendak berwakaf uang.

Materi yang efektif hendaklah disusun sesuai dengan kondisi masyarakat. Termasuk disediakan pula materi khutbah atau dakwah dengan Bahasa daerah. Ini akan lebih efektif karena melalui bahasa daerah masing-masing akan lebih memberikan pemahaman yang dalam kepada masyarakat.

\section{c. Menyelenggaran Training of Trainer bagi para Khatib dan Da'i}

Training of Trainer (TOT) atau Pelatihan untuk Pelatih merupakan pelatihan yang diperuntukkan bagi orang yang diharapkan setelah selesai pelatihan mampu menjadi pelatih dan mampu mengajarkan materi pelatihan tersebut kepada orang lain. ${ }^{48}$

Penyelenggaran TOT terhadap para khatib dan da'i tentang wakaf uang jelas sangat mendesak, karena mereka corong pertama ke 
masyarakat. Dalam kemampuan beretorika para khatib dan da'i ini memiliki kehandalan yang teruji. Namun,bagi mereka perlu diberikan pelatihan yang pada akhirnya akan mampu mendorong wakaf lebih tersosialisasi dengan lebih baik lagi.

Peningkatkan kompetensi dai, khatib, ketua DKM, pimpinan majelis taklim melalui TOT ini difokuskan bagi mereka yang berada di tingkat Kota dan Kabupaten. Peserta yang harus mengikuti kegiatan ini adalah para Ketua DKM, Khatib, penyuluh Agama Islam baik yang PNS maupun Non-PNS, guru madrasah dan pimpinan majelis taklim yang sehari-harinya bergelut di bidang keagamaan dan bergaul secara langsung dengan masyarakat, bahkan sebagai mauqufalaihi dari program wakaf uang untuk kedepannya

\section{Kesimpulan}

Wakaf uang di Indonesia belum terlaksana secara optimal. Hal ini dikarenakan kurangnya literasi di masyarakat. Indeks Literasi Wakaf di Indonesia menempati skor rendah, bahkan preferensi masyarakat terhadap wakaf uang belum menguat tapi masih cenderung mewakafkan benda bergerak.

Problem kurangnya literasi wakaf uang di Indonesia bisa diselesaikan salah satunya literasi wakaf uang berbasis Masjid. Para pihak terkait, dalam hal ini Kementerian Agama dan Badan Wakaf Indonesia (BWI) yang berada di level Kota Kabupaten sudah seharusnya mengadakan kegiatan edukasi dan literasi berbasis Masjid. Dengan kegiatan tersebut masyarakat akan mendapatkan akses untuk mendapatkan pengetahuan tentang wakaf uang.

Salah satu strategi dalam literasi wakaf uang berbasis masjid ini dapat dilakukan dengan cara sebagai berikut membangun kerjasama organisasi yang memiliki tugas dan fungsi pembinaan kemasjidan, diantaranya Dewan Masjid Indonesia (DMI), Badan Koordinasi Majelis 
Taklim Masjid (BKMM) dan Badan Komunikasi Pemuda Remaja Masjid (BKPRMI).

Selain itu, pihak terkait perlu juga menyusun materi Majeis Taklim dan khutbah tentang wakaf uang supaya menjadi bekal materi bagi para da'i dan khatib dalam berbagai kegiatan ceramah, baik pengajian ataupun khutbah jumat. Dengan tersusunnya materi materi yang baik, diharapkan literasi kepada masyarakat secara langsung dapat tercapai. Kemudian program berikutnya adalah menyelenggaran Training of Trainer bagi para Khatib dan Da'i. Dengan adanya Training of Trainer (TOT) atau Pelatihan untuk Pelatih diharapkan setelah selesai pelatihan, para ulama mampu menjadi pelatih dan mampu mengajarkan materi pelatihan tersebut kepada orang lain.

Saran yang diajukan dari penelitian ini adalah Kementerian Agama, Dewan Masjid Indonesia (DMI), BKMM, BKPRMI, Pemerintah Daerah dan tokoh agama agar melakukan kerjasama intensif guna pelaksanaan literasi wakaf uang berbasis masjid terutama untuk daerah pedesaan. Melaksanakan sosialisasi kepada masjid-masjid melalui ketiga organisasi kemasjidan tersebut tentang manfaat wakaf uang berbasis masjid. Literasi wakaf uang berbasis masjid ini jelas akan memberikan pengarus positif terhadap kesejahteraan masyarakat secara nasional. 


\section{Daftar Pustaka}

Al-Anshari, Abu Yahya Zakariya. Fath Al-Wahhab. Bandung: Syirkah AlMu'awanah, t.t.

Al-Buthy, Muhammad Sa'id Ramadhan. Sirah Nabawiyah: Analisis Ilmiah Manhajiah Sejarah Pergerakan Islam Di Masa Rasulullah SAW. Editor Aunur Rafiq Shaleh Tahmid. Jakarta: Robbani Press, 2000.

Al-Habsyiy, Sayyid Utsman. "Praktek Pelaksanaan Wakaf Di Malaysia." In Sistem Pengelolaan Waqaf Dalam Aplikasinya Di Masa Kini (ContohContoh Terpilih Dari Praktek Waqaf Di Berbagai Negara Dan Masyarakat Islam), editor Mahmud Ahmad Mahdiy, Jakarta: BWI, 2015.

Amin, Kamaruddin. Penguatan Sosialisasi dan Literasi Wakaf Nasional. disampaikan pada Rakornas BWI tanggal 30 Maret 2021. Jakarta: Ditjen Bimas Islam, 2021.

An-Nawawi, Zakariya Muhyiddin ibn Syaraf. Al-Majmu' Syarh AlMuhadzdzab. Bairut: Dar al-Fikr, 2000.

Athoillah, H. M. Hukum Wakaf Benda Bergerak. Sumedang: Alqaprint Jatinangor, 2012.

BWI. Handbook Tanyajawab Wakaf Uang. Jakarta: BWI, 2013.

Darmaji, Amalla Rizki Putri dan Maison. “Kerjasama Dan Kekompakan Siswa Dalam Pembelajaran Fisika Di Kelas XII MIPASMAN 3 Kota Jambi" 3, no. 2 (2018): 32-40.

Direktorat Pengembangan Zakat dan Wakaf. Paradigma Baru Wakaf Di Indonesia. Jakarta: Dirjen Bimas dan Penyelenggara Haji, 2004. 
Girindra Mega Paksi, Asfi Manzilati, Marlina Ekawaty. “Kajian Hukum Dan Implementasi Wakaf Harta Bergerak Di Indonesia: Wakaf Uang Dan Saham." Islamic Economic: Jurnal Ekonomi Islam 9, no. 2 (2018): 173-90.

Hamdan, Yusuf. "Karakteristik Khutbah Jumat Di Mesjid Kampus: Perspektif Komunikasi." Mediator: Jurnal Komunikasi 8, no. 2 (2007): 353-68.

Hasanah, Uswatun. “Laporan Akhir Pengkajian Hukum Tentang Aspek Hukum Wakaf Uang." Badan Pembinaan Hukum Nasional Departemen Hukum Dan Hak Asasi Manusia, Jakarta: BPHN, 2009.

John M Echols \& Hasan Shadily. Kamus Inggris Indonesia: An EnglishIndonesian Dictionary. Jakarta: Gramedia, 2003.

Kementerian Keuangan RI. “Kajian Pengembangan Wakaf Uang Dalam Rangka Pendalaman Pasar Keuangan Syariah." Ringkasan Eksekutif, Jakarta: Kemenkeu, 2019.

Kharizmi, Muhammad. "Kesulitan Siswa Sekolah Dasar Dalam Meningkatkan Kemampuan Literasi." Jurnal Pendidikan Almuslim, VII, no. 2 (2019): 94-102.

Makmun, Moh., dan Mahmud Huda. “Politisasi Masjid Perspektif Fiqh Siyasah: Studi Terhadap Takmir Masjid Di Kota Surabaya." Jurnal Politik Profetik 7, no. 1 (2019): 97-120.

Maulany, H. R. Panduan Pengurus Masjid Di Indonesia. Editor Asep Salahudin. Bandung: Kakita Mandiri, 2015.

Meylianingrum, Kurniawati, Muhammad Muhajir Aminy, dan Mohd Aslam Mizan Aslam. "Wakif Preferences In Selecting Cash Waqf: A Case of Badan Wakaf Indonesia at Yogyakarta City." Ikonomika 5, 
no. 1 (2020): 85-100.

Mubarok, Jaih. Wakaf Produktif. Bandung: Kanwil Departemen Agama Provinsi Jawa Barat, 2009.

Setiyanti, Sri Wiranti. “Membangun Kerjasama Tim (Kelompok)." Jurnal STEI Semarang 4, no. 3 (2012): 1-25.

Shihab, M. Quraish. Wawasan Al-Quran: Tafsir Maudhu'i Atas Pelbagai Persoalan Umat. IX. Bandung: Mizan, 1999.

Suhilmiati, Endhang. “Revitalisasi Pendidikan Karakter Melalui Kegiatan Training Of Trainer (ToT)." Intelektual: Jurnal Pendidikan Islam 7, no. 2 (2017): 175-80.

Sukma, Elfia, Ritawati Mahjuddin, dan Rizky Amelia. "Literacy Media Development in Improving Reading and Writing Skill of Early Class Students in Elementary School Padang Utara Padang." In 9th International Conference for Science Educators and Teachers (ICSET), 118:145-50. Atlantis Press, 2017. https://doi.org/10.2991/ icset-17.2017.25.

Suryani, Yunal Isra. "Wakaf Produktif (Cash Waqf) Dalam Perspektif Hukum Islam Dan Maqasid Al-Shari'ah." Walisongo: Jurnal Penelitian Sosial Keagamaan 24, no. 1 (2016): 17-36.

Tim Penulis BWI. Himpunan Peraturan Perundang-Undangan Tentang Wakaf. Jakarta: Badan Wakaf Indfonesia, 2018.

Tohor, Tarmizi. Gerakan Wakaf Uang Nasional Sebagai Momentum Kebangkitan Wakaf. disampaikan pada Literasi Wakaf Uang Bagi Da'i dan Daiyah tanggal 6 April 2021. Jakarta: Direktorat Pemberdayaan Zakat dan Wakaf, 2021. 
Wahyudiana, Darodjat dan. "Memfungsikan Masjid Sebagai Pusat Pendidikan Untuk Membentuk Peradaban Isalam." Islamadina XIII, no. 2 (2014): 1-13.

Wahyuni, Sri. "Menumbuhkembangkan Minat Baca Menuju Masyarakat Literat." Diksi 17, no. 1 (2015): 179-89.

\section{Internet}

Badan Wakaf Indonesia. "Laporan Hasil Survey Indeks Literasi Wakaf 2020." Vol. 1. Jakarta, 2020. Diakses tanggal 10 April 2021 https:// www.bwi.go.id/wp-content/uploads/2020/05/Laporan-SurveyLiterasi-Wakaf-Nasional-Tahun-2020.pdf.

BKPRMI. “AD ART BKPRMI.” BKPRMI, 2021. Diakses tanggal 08 dan 10 April 2021 https://bkprmi.or.id/ad-art/.

BPMI Setpres. "Presiden Jokowi Luncurkan Gerakan Nasional Wakaf Uang." Biro Pers, Media, dan Informasi Sekretariat Presiden. Accessed April 8, 2021. Diakses tanggal 8 April 2021 https://www. presidenri.go.id/siaran-pers/presiden-jokowi-luncurkan-gerakannasional-wakaf-uang/\#: :text=Presiden Joko Widodo meluncurkan Gerakan,diikuti sejumlah hadirin secara virtual.

Dewan Masjid Indonesia. "Profil DMI." Dewan Masjid Indonesia, 2021. Diakses tanggal 08 dan 09 April 2021 http://dmi.or.id/gallery/ profil-dmi/.

Hendri Tanjung, “Gerakan Nasional Wakaf Uang 2021,” Badan Wakaf Indonesia, 2021. Diakses tanggal 10 April 2021. https://www.bwi. go.id/5806/2021/01/21/gerakan-nasional-wakaf-uang-2021/. 
Kemenag RI. “Jumlah Tanah Wakaf Seluruh Indonesia." Kementerian Agama RI, 2021. Diakses tanggal 8 April 2021 http://siwak.kemenag. go.id/tabel_jumlah_tanah_wakaf.php.

Majelis Ulama Indonesia. "Fatwa MUI," 2002. Diakses tanggal 9 April 2021 http://mui.or.id/wp-content/uploads/files/fatwa/29.-WakafUang.pdf.

Sistem Informasi Masjid. "Data Masjid." Ditjen Bimas Islam, 2021. Diakses tanggal 08 April 2021 https://simas.kemenag.go.id/. 


\section{Endnotes}

1. Kamaruddin Amin, Penguatan Sosialisasi dan Literasi Wakaf Nasional, disampaikan pada Rakornas BWI tanggal 30 Maret 2021, (Jakarta: Ditjen Bimas Islam, 2021), h. 3. lihat Hendri Tanjung, "Gerakan Nasional Wakaf Uang 2021," Badan Wakaf Indonesia, 2021. Diakses tanggal 10 April 2021. https://www.bwi.go.id/5806/2021/01/21/gerakan-nasional-wakafuang-2021/.

2. Kemenag RI, “Jumlah Tanah Wakaf Seluruh Indonesia," Kementerian Agama RI, 2021. Diakses tanggal 08 April 2021. http://siwak.kemenag.go.id/ tabel_jumlah_tanah_wakaf.php. diakses pada tanggal 08 April 2021.

3. Sayyid Utsman Al-Habsyiy, "Praktek Pelaksanaan Wakaf Di Malaaysia," in Sistem Pengelolaan Waqaf Dalam Aplikasinya Di Masa Kini (Contoh-Contoh Terpilih Dari Praktek Waqaf Di Berbagai Negara Dan Masyarakat Islam), editor Mahmud Ahmad Mahdiy, (Jakarta: BWI, 2015), 119-32.

4. Tarmizi Tohor, Gerakan Wakaf Uang Nasional Sebagai Momentum Kebangkitan Wakaf, disampaikan pada Literasi Wakaf Uang Bagi Da'i dan Daiyah tanggal 6 April 2021, (Jakarta: Direktorat Pemberdayaan Zakat dan Wakaf, 2021), 15.

5. Jaih Mubarok, Wakaf Produktif (Bandung: Kanwil Departemen Agama Provinsi Jawa Barat, 2009), 125.

6. Uswatun Hasanah, Laporan Akhir Pengkajian Hukum Tentang Aspek Hukum Wakaf Uang, (Jakarta: Badan Pembinaan Hukum Nasional Departemen Hukum Dan Hak Asasi Manusia, 2009), 22.

7. Tim Penulis BWI, Himpunan Peraturan Perundang-Undangan Tentang Wakaf (Jakarta: Badan Wakaf Indfonesia, 2018), 3.

8. BPMI Setpres, "Presiden Jokowi Luncurkan Gerakan Nasional Wakaf Uang," Biro Pers, Media, dan Informasi Sekretariat Presiden. Diakses tanggal 08 April 2021. https://www.presidenri.go.id/siaran-pers/presiden-jokowiluncurkan-gerakan-nasional-wakaf-uang/\#: :text=Presiden Joko Widodo meluncurkan Gerakan,diikuti sejumlah hadirin secara virtual.

9. Kementerian Keuangan RI, “Kajian Pengembangan Wakaf Uang Dalam Rangka Pendalaman Pasar Keuangan Syariah," Ringkasan Eksekutif, (Jakarta: 
Kemenkeu, 2019), 5.

10. Badan Wakaf Indonesia, “Laporan Hasil Survey Indeks Literasi Wakaf 2020," vol. 1, (Jakarta, 2020), 6. Diakses tanggal 10 April 2021. https://www. bwi.go.id/wp-content/uploads/2020/05/Laporan-Survey-Literasi-WakafNasional-Tahun-2020.pdf.

11. Badan Wakaf Indonesia, “Laporan Hasil Survey..., 11.

12. Amin, "Penguatan Sosialisasi dan Literasi ..., 8.

13. Sistem Informasi Masjid, “Data Masjid,” Ditjen Bimas Islam. Diakses tanggal 08 April 2021. https://simas.kemenag.go.id/.

14. H. M. Athoillah, Hukum Wakaf Benda Bergerak, (Sumedang: Alqaprint Jatinangor, 2012), 1.

15. Zakariya Muhyiddin ibn Syaraf An-Nawawi, Al-Majmu' Syarh AlMuhadzdzab, (Bairut: Dar al-Fikr, 2000), 225.

16. Abu Yahya Zakariya Al-Anshari, Fath Al-Wahhab, (Bandung: Syirkah AlMu'awanah, t.t.), 256-57.

17. Athoillah, Hukum Wakaf Benda Bergerak..., 6.

18. Tim Penulis BWI, Himpunan Peraturan Perundang-Undangan ..., 4.

19. Direktorat Pengembangan Zakat dan Wakaf, Paradigma Baru Wakaf Di Indonesia (Jakarta: Dirjen Bimas dan Penyelenggara Haji, 2004), 63-85.

20. Mubarok, Wakaf Produktif..., 131-38.

21. Marlina Ekawaty Girindra Mega Paksi, Asfi Manzilati, “Kajian Hukum Dan Implementasi Wakaf Harta Bergerak Di Indonesia: Wakaf Uang Dan Saham," Islamic Economic: Jurnal Ekonomi Islam 9, no. 2 (2018): 173-90.

22. Ibid.

23. Majelis Ulama Indonesia, "Fatwa MUI," 2002. Diakses tanggal 09 April 2021. http://mui.or.id/wp-content/uploads/files/fatwa/29.-Wakaf-Uang.pdf.

24. Tim Penulis BWI, Himpunan Peraturan Perundang-Undangan..., 4.

25. Ibid, 313 .

26. BWI, Handbook Tanyajawab Wakaf Uang (Jakarta: BWI, 2013), 2. 
27. Yunal Isra, Suryani, “Wakaf Produktif (Cash Waqf) Dalam Perspektif Hukum Islam Dan Maqasid Al-Shari'ah," Walisongo: Jurnal Penelitian Sosial Keagamaan 24, no. 1 (2016): 17-36.

28. Kurniawati Meylianingrum, Muhammad Muhajir Aminy, dan Mohd Aslam Mizan Aslam, "Wakif Preferences In Selecting Cash Waqf: A Case of Badan Wakaf Indonesia at Yogyakarta City," Ikonomika 5, no. 1 (2020): 85-100,

29. M. Quraish Shihab, Wawasan Al-Quran: Tafsir Maudhu'i Atas Pelbagai Persoalan Umat, IX (Bandung: Mizan, 1999), 459.

30. Darodjat dan Wahyudiana, "Memfungsikan Masjid Sebagai Pusat Pendidikan Untuk Membentuk Peradaban Isalam," Islamadina XIII, no. 2 (2014): 1-13.

31. Muhammad Sa'id Ramadhan Al-Buthy, Sirah Nabawiyah: Analisis Ilmiah Manhajiah Sejarah Pergerakan Islam Di Masa Rasulullah SAW, editor: Aunur Rafiq Shaleh Tahmid, (Jakarta: Robbani Press, 2000), 158.

32. Al-Buthy, Sirah Nabawiyah: Analisis Ilmiah..., 169-171.

33. H. R. Maulany, Panduan Pengurus Masjid Di Indonesia, ed. Asep Salahudin (Bandung: Kakita Mandiri, 2015), 6-10.

34. Sistem Informasi Masjid, “Data Masjid," Ditjen Bimas Islam, diakses tanggal 08 April 2021. https://simas.kemenag.go.id/.

35. Sistem Informasi Masjid, "Data Masjid," Ditjen Bimas Islam, diakses tanggal 08 April 2021. https://simas.kemenag.go.id/.

36. Moh. Makmun dan Mahmud Huda, "Politisasi Masjid Perspektif Fiqh Siyasah: Studi Terhadap Takmir Masjid Di Kota Surabaya," Jurnal Politik Profetik 7, no. 1 (2019): 97-120.

37. John M Echols \& Hasan Shadily, Kamus Inggris Indonesia: An English Indonesian Dictionary. (Jakarta: Gramedia, 2003), 361.

38. Elfia Sukma, Ritawati Mahjuddin, dan Rizky Amelia, “Literacy Media Development in Improving Reading and Writing Skill of Early Class Students in Elementary School Padang Utara Padang," in 9th International Conference for Science Educators and Teachers (ICSET), vol. 118 (Atlantis Press, 2017), 145-50, https://doi.org/10.2991/icset-17.2017.25. 
39. Sri Wahyuni, "Menumbuhkembangkan Minat Baca Menuju Masyarakat Literat," Diksi 17, no. 1 (2015): h. 179-89.

40. Muhammad Kharizmi, "KesulitanSiswaSekolah DasarDalam Meningkatkan Kemampuan Literasi," Jurnal Pendidikan Almuslim, VII, no. 2 (2019): 94-102.

41. Amalla Rizki Putri \& Maison \& Darmaji, "Kerjasama Dan Kekompakan Siswa Dalam Pembelajaran Fisika Di Kelas XII MIPASMAN 3 Kota Jambi" 3, no. 2 (2018): 32-40.

42. Sri Wiranti Setiyanti, "Membangun Kerjasama Tim (Kelompok)," Jurnal STEI Semarang 4, no. 3 (2012): 1-25.

43. Dewan Masjid Indonesia, “Profil DMI," Dewan Masjid Indonesia, 2021. Diakses tanggal 08 April 2021. http://dmi.or.id/gallery/profil-dmi/.

44. BKPRMI, "AD ART BKPRMI," BKPRMI, 2021. Diakses tanggal 08 April 2021. https://bkprmi.or.id/ad-art/.

45. Dewan Masjid Indonesia, "Profil DMI," Dewan Masjid Indonesia, 2021. Diakses tanggal 09 April 2021. http://dmi.or.id/gallery/profil-dmi/.

46. BKPRMI, "AD ART BKPRMI," BKPRMI, 2021, Diakses tanggal 10 April 2021. https://bkprmi.or.id/ad-art/.

47. Yusuf Hamdan, “Karakteristik Khutbah Jumat Di Mesjid Kampus: Perspektif Komunikasi," Mediator: Jurnal Komunikasi 8, no. 2 (2007): 353-68.

48. Endhang Suhilmiati, "Revitalisasi Pendidikan Karakter Melalui Kegiatan Training Of Trainer (ToT)," Intelektual: Jurnal Pendidikan Islam 7, no. 2 (2017): 175-80. 